\title{
岩手県北上市付近の火山灰土壤の生成について
}

\author{
第 2 報 母材 と土壤生 成 \\ 小野 㴊志2) · 庄子貞 雄 ${ }^{2}$
}

\section{Genesis of Andosols at Kitakami, Iwate Prefecture, Northeast Japan ${ }^{1)}$}

\section{Relationships between Parent Materials and Soil Formation}

\author{
Tsuyoshi $\mathrm{ONO}^{2)}$ and Sadao ShojI ${ }^{2)}$
}

\begin{abstract}
The distribution of Andosols and their relation to topography were clarified in the previous paper. In the present report the relationship between parent materials and soil formation is discussed.

Cumulative tepha layers from the top to the Murasakino pumice are divided into three groups; younger dacitic ash (1,000 to 5,000 years B.P.), older andesitic ash (10,000 to 20,000 years B.P.) and Murasakino pumice $(20,000$ or more years B.P.). Each ash group also consists of several ash layers. Since most tephra layers were brought to the surface intermittently, they were subjected to surface weathering. Therefore, the degree of weathering of hypersthene and/or augite in the Andosols shows a tendency to become greater with the depth of soil profiles.

All the Andosols on the Kanagasaki terrace show the rejuvenation type of humus horizons formed of younger dacitic ash which covered the alluvial deposits.

The formation of Andosols on the Murasakino terrace was found to be closely related to the depositional features of the parent materials, to the mixing of the soils atrificially and to the truncation and redeposition of the soils. Tephra layers from the top to the Murasakino pumice were found in the profile of Normal Andosol. However, the Al horizon of this Andosol contains more or less the parent material belonging to the subsoil in addition to the parent materials which are common to the same horizon of Normal Andosol on the Kanagasaki terrace. It was noted that these materials were well mixed. Light-colored Andosol (II) was formed after the truncation of the Al horizon of Normal Andosol on the same terrace. Aquic Andosol was formed by the redeposition of eroded materials in the valley bottom.

Light-colored (II) and Aquic Andosols on the Nishine terrace were formed by truncation and redeposition, respectively, as observed in the Murasakino terrace. However, the formation of these soils was found to be more advanced on the Nishine terrace which is more strongly dissected.
\end{abstract}

\section{I. 緒}

論

母材としてのテフラ（降下火砕堆積物）は，一般に細 粒であるため表面積が大きく，乙かも風化抵抗性の最も 小さい火山ガラスが鉱物組成の大半ないし，大部分を占 めているので，きわめて風化を受け易いといら特徵があ げら秃る。字た火山活動は一般に長期間に亘って継続す るので,テフラの降下もくり返し行なわれることになる。
このため火山灰土壊は，くり返し母材の供給あるいは更 新を受けることになる・したがっててのような母材の特 徵は, 火山灰土壤の風化生成や土壤の諸性質化刘して, 他の土壤にはみられない注目すべき影響を与える。さら にわが国のように多雨条件下にあって，古い時代から人 為が土壤に加えられている所では，侵蝕による母材の移 動も大きな問題とならう。しかしながら従来の研究をみ ると，火山灰土壤の生成汇対する母材の累積性や侵蝕移

1) 1977 年 7 月 13 日受付

2) 東北大学濃学部. Faculty of Agriculture, Tohoku University. 


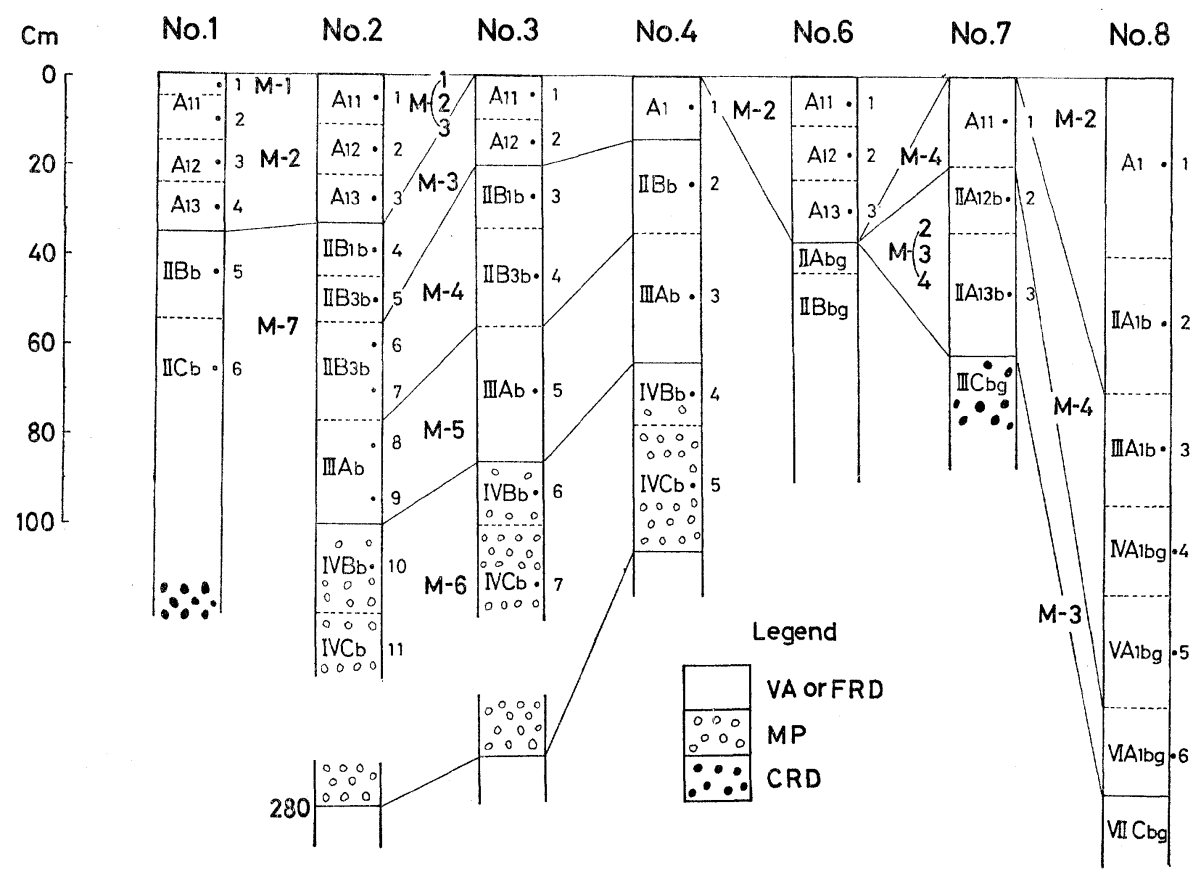

図 1 代表土壤断面の柱状四

凡例 VA; 火山灰層, FRD; 細粘河川堆積物, MP ; 村崎野軽石層, GRD ; 粗粒河川堆積物

動の関係は比較的軽視されて来たように見受けられる。

そこで，本研究では，前報（庄子·小野，1978）で明 らかにした北上市付近の火山灰土壤について，とくに母 材の累積性に重点をおいて，母材と土壤生成の関係につ いて検討安行なった結果䒚報告する。なお母材の識別 は，強磁性鉱物の化学組成を中心に，重鉱物組成および その風化程度, 土壤断面の特徵などにもとづいて総合的 に扔てなった。

\section{II. 試料と実験方法}

供試土壤は第 1 報で用いた各地形面每の代表土壤であ る.図 1 にはそ机らの層序打よび母材の識別のために， 供試した土壤の採取位置を示した. また, 本地域の平安 初期の遺跡中に見出された新鮮な火山灰も採取して分析 に供した. 図中，M-1 から M-7 までの記号は, 後述 する強磁性鉱物の化学組成によって区分できたテフラの 層序単位である.

強磁性鉱物の分離精製と分析法 : 庄子ほか，(1974）は 北海道と本州の多くのテフラ中に含まれる強磁性鉱物の 化学組成について研究を行ない, 強磁性鉱物中の Zn, $\mathrm{V}, \mathrm{Mn}$, な゙の微量元素は, テフラの同定や噴出源の判 等に有效であることを明らかにした。この有效性は，長
友添か (1976) によって九州のテフラについても確認さ れている.さらに庄子ほか (1975) は，これらの微量元 素含量が，テフラの岩質とよく対応する事定明らかにし た．そこで本地域のテフラの識別にもこの方法を利用す ることにした。

強磁性鉱物の分離精製は次の通りである.腐植含量の 高い土壤の場合は $\mathrm{H}_{2} \mathrm{O}_{2}$ で腐植を分解乙，腐植をほとえ ぞ含まないものはそのまま水中で超音波処理で土壤を分 散してから，磁石で強磁性鉱物を分離した．軽石や新期 火山灰は磁性乳鉢で十分粉厒した後，同様に水中で強磁 性鉱物空分離した．さらに分離した強磁性鉱物中の不純 物索除くために，メノウの乳鉢で磨挽しマグネチックス ターラーではげしく掜汼して浮遊物を除去した。 この操 作を 3 回以上繰り返して純度を上げた.

強磁性鉱物の分析法は次の通りである。試料約 $0.1 \mathrm{~g}$ を $30 \mathrm{ml}$ テフロンビーカーに取り, 王水 $5 \mathrm{ml}$ と $\mathrm{HF}$ (47 \%) $2 \mathrm{ml}$ 学加光，ホットプレート上で徐々に加熱し最 後には約 $200^{\circ} \mathrm{G}$ 宗で加熱して分解した。蒸発乾固後, $6 \mathrm{~N}-\mathrm{HCl} 5 \mathrm{~m} l$ 加光て加温溶解し, 冷却後純水它加兑 て定容として分析に供した。全 Fe は O-フェナンスロ リン法, Ti は夕イロン法, V は BPA 法, Zn は原子吸 光法によった。 


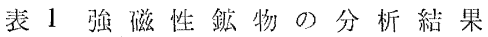

\begin{tabular}{|c|c|c|c|c|c|c|c|}
\hline 試 & 層＼cjkstart位 & $\begin{array}{c}\mathrm{Zn} \\
(\mathrm{ppm})\end{array}$ & $\begin{array}{c}\mathrm{V} \\
(\mathrm{ppm})\end{array}$ & $\begin{array}{l}\mathrm{Fe} \\
(\%)\end{array}$ & $\begin{array}{c}\mathrm{Ti} \\
(\%) \\
\end{array}$ & $\begin{array}{l}\mathrm{V}-\mathrm{Zn} \text { ベル } \\
\text { ト上の位置 }\end{array}$ & 母材の岩質 \\
\hline $\begin{array}{ll}\text { 新鮮火山灰 } & 1^{*} \\
& 2 \\
3\end{array}$ & & $\begin{array}{l}797 \\
716 \\
744\end{array}$ & $\begin{array}{l}1,727 \\
1,701 \\
1,792\end{array}$ & $\begin{array}{l}54.83 \\
50.11 \\
51.07\end{array}$ & $\begin{array}{r}11.03 \\
9.99 \\
9.93\end{array}$ & $\begin{array}{c}M-1 " \\
" 1 "\end{array}$ & 石英安山岩 \\
\hline No. $\begin{aligned} 1 & -1 \\
& -1^{\prime * * *} \\
& =2 \\
& -3 \\
& -4 \\
& =5 \\
& -6\end{aligned}$ & $\begin{array}{l}\mathrm{A}_{11} \\
\mathrm{~A}_{11} \\
\mathrm{~A}_{11} \\
\mathrm{~A}_{12} \\
\mathrm{~A}_{13} \\
\text { II } \mathrm{B}_{\mathrm{b}} \\
\text { II } \mathrm{C}_{\mathrm{b}}\end{array}$ & $\begin{array}{r}826 \\
849 \\
679 \\
633 \\
646 \\
1,392 \\
1,186\end{array}$ & $\begin{array}{l}2,350 \\
1,865 \\
2,391 \\
2,111 \\
2,436 \\
3,095 \\
3,148\end{array}$ & $\begin{array}{l}55.68 \\
55.36 \\
56.23 \\
54.57 \\
55.94 \\
57.50 \\
57.36\end{array}$ & $\begin{array}{l}8.03 \\
8.18 \\
8.56 \\
8.32 \\
6.41 \\
7.10 \\
7.16\end{array}$ & $\begin{array}{c}M-1 \\
M-2 \\
\text { "1" } \\
M-7\end{array}$ & 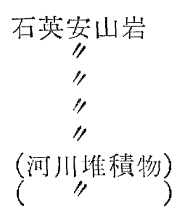 \\
\hline $\begin{aligned} \text { No. } 2-1 \\
-2 \\
=3 \\
=4 \\
=5 \\
=6 \\
=7 \\
=8 \\
=9 \\
-10\end{aligned}$ & $\begin{array}{l}\mathrm{A}_{11} \\
\mathrm{~A}_{12} \\
\mathrm{~A}_{13} \\
\text { II } \mathrm{B}_{1 \mathrm{~b}} \\
\text { II } \mathrm{B}_{3 \mathrm{~b}} \\
\text { II } \mathrm{B}_{3 \mathrm{~b}} \\
\text { II } \mathrm{B}_{3 \mathrm{~b}} \\
\text { III } \mathrm{A}_{\mathrm{b}} \\
\text { III } \mathrm{A}_{\mathrm{b}} \\
\text { III } \mathrm{B}_{\mathrm{b}}\end{array}$ & $\begin{array}{l}717 \\
726 \\
716 \\
631 \\
664 \\
718 \\
709 \\
652 \\
631\end{array}$ & $\begin{array}{l}2,591 \\
2,694 \\
2,651 \\
2,866 \\
3,176 \\
2,734 \\
2,979 \\
3,524 \\
3,542\end{array}$ & $\begin{array}{l}57.79 \\
57.83 \\
57.84 \\
60.67 \\
62.56 \\
61.90 \\
62.23 \\
63.18 \\
62.56\end{array}$ & $\begin{array}{l}6.87 \\
6.93 \\
6.43 \\
6.35 \\
6.60 \\
6.96 \\
6.71 \\
6.28 \\
6.23\end{array}$ & $\begin{array}{c}M-2^{\prime} \\
\text { "1" } \\
M-3 \\
M-4 \\
M-5 \\
" 1 " 4\end{array}$ & $\begin{array}{c}\text { 石英宽山岩 } \\
\text { " } \\
\text { 安 岩 } \\
\text { "” } \\
\text { "” } \\
\text { " } \\
\text { " }\end{array}$ \\
\hline $\begin{aligned} \text { No. } 3-1 \\
-2 \\
-3 \\
-4 \\
-5 \\
-6 \\
-7\end{aligned}$ & $\begin{array}{l}\mathrm{A}_{11} \\
\mathrm{~A}_{12} \\
\text { II } \mathrm{B}_{3 \mathrm{~b}} \\
\text { II } \mathrm{B}_{2 \mathrm{~b}} \\
\text { III } \mathrm{A}_{\mathrm{b}} \\
\text { III } \mathrm{B}_{\mathrm{b}} \\
\text { III } \mathrm{C}_{\mathrm{b}}\end{array}$ & $\begin{array}{l}643 \\
631 \\
740 \\
726 \\
652 \\
574 \\
541\end{array}$ & $\begin{array}{l}3,276 \\
3,055 \\
3,281 \\
3,301 \\
3,535 \\
3,829 \\
3,603\end{array}$ & $\begin{array}{l}60.47 \\
57.83 \\
62.77 \\
62.53 \\
62.73 \\
61.05 \\
62.67\end{array}$ & $\begin{array}{l}6.91 \\
6.76 \\
6.58 \\
6.56 \\
6.16 \\
5.87 \\
6.29\end{array}$ & $\begin{array}{l}M-3 \\
M-4 \\
M-5 \\
M-6 \\
\text { "1" }\end{array}$ & $\begin{array}{c}\text { 安岁岩 } \\
\text { "1 } \\
\text { " } \\
\text { " } \\
\text { " }\end{array}$ \\
\hline $\begin{aligned} \text { No. } 4-1 \\
-2 \\
-3 \\
=4 \\
-5\end{aligned}$ & $\begin{array}{l}\mathrm{A}_{1} \\
\text { II } \mathrm{B}_{\mathrm{b}} \\
\text { III } \mathrm{A}_{\mathrm{b}} \\
\text { II } \mathrm{B}_{\mathrm{b}} \\
\text { IV } \mathrm{C}_{\mathrm{b}}\end{array}$ & $\begin{array}{l}645 \\
690 \\
667 \\
588 \\
558\end{array}$ & $\begin{array}{l}2,962 \\
3,302 \\
3,404 \\
3,633 \\
3,663\end{array}$ & $\begin{array}{l}61.46 \\
61.70 \\
62.55 \\
65.22 \\
61.29\end{array}$ & $\begin{array}{l}6.97 \\
6.47 \\
6.14 \\
6.40 \\
6.02\end{array}$ & $\begin{array}{l}M-3 \\
M-4 \\
M-5 \\
M-6\end{array}$ & $\begin{array}{c}\text { 安山岩 } \\
\text { "” } \\
\text { " } \\
\text { " }\end{array}$ \\
\hline
\end{tabular}

* 平安初期の堅穴中で採取した火山灰

** No. 1 地点の近くで採取したもので No. $1-1$ と同一層

重鉱物組成の決定法: 土壤写 $6 \% \mathrm{H}_{2} \mathrm{O}_{2}$ で処理して有 機物定除き, 音波処理後, 脱鉄処理 (MEHRA and JACK-

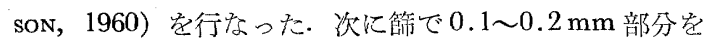
集め，テトラブロムエタン（此重 2.96）で重鉱物を分離 し, 重鉱物含量它求めた. 重鉱物組成法偏光顕微鏡下で 200〜300 粒検鏡して決定した.

重鉱物の風化程度：火山灰土壤の風化程度を推定する ためには，その中に含悉れる重鉱物，とくに普通輝不の 溶蝕の程度を知る事が有効であるととが知られている (弘法·大羽, 1973 ; Shojr et al., 1974). そこで本地域 の火山灰土裹にもこの方法を適用した．乙かし普通輝石 の少ない下層土では,その代わりにシソ輝不を使用した。 溶蝕程度は次の 4 段階に区分した.
0 : 溶蝕を受けていない。
1: 溶蝕を弱く受けている.
$2:$ 溶強学中程度受けている。

\section{$3:$ 溶蝕学強く受けている.}

\section{III. 結果 と考察}

中川ほか（1963）によれば，村崎野軽石層を最下部之 する黑沢层火山灰は, 村崎野段丘掠よび西根段丘を抢お い，最も新しい金々崎段丘には存在しないという。しか しながら前報（庄子・小野，1978）では，金ケ崎段丘上 の火山灰土壤は阫植層のみからなり村崎野軽石層をとも なっていないこと, また土壤断面の特徴からみて, 村崎 野段丘や西根段丘上の黒沢尻火山灰には，かなり長期間 地表風化を受けたと少られる粘土含量の高い，赤味の強 い埋没土層が 2 枚含まれていること(例えば黒ボク土 No. 2 の断面では $\mathbb{I I} \mathrm{B}_{1 \mathrm{~b}}$ と II $\mathrm{Ab}$ 層) などから, 黑沢尻 火山灰が何回かの降灰による累積性のるのであることが うかがわれた。

表 1 亿は, 各地形面の火山灰土壤上り分離した強磁性 


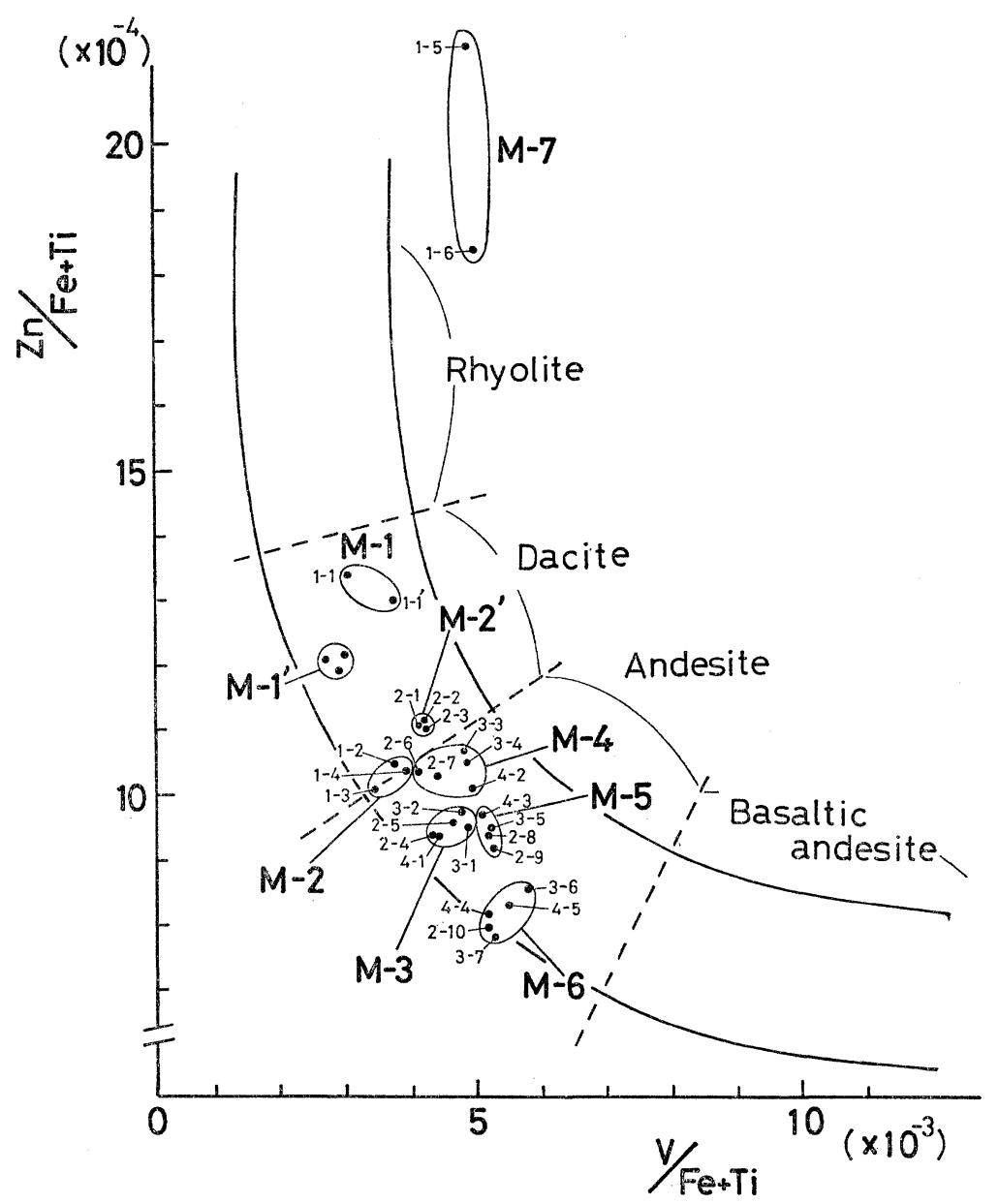

図 2 強磁性鉱物の $\mathrm{V}-\mathrm{Zn}$ ベルト

鉱物の $\mathrm{Zn}, \mathrm{V}, \mathrm{Fe}, \mathrm{Ti}$ 含量を示した。庄子ほか (1974)， SHOJi et al., (1975) は, 強磁性鉱物中の微量元素炎利 用するにあたり，不純物混入の影響を出来るだけ軽減す るために，各元素の絶対量の代りに他の多量元素との比 を用いることが有効である事を明らかにした，そこで 表 1 の各元素の分析結果から $\mathrm{V} / \mathrm{Fe}+\mathrm{Ti}$ と $\mathrm{Zn} / \mathrm{Fe}+\mathrm{Ti}$ の元素の重量比を求め, テフラの識別および母材の岩質 判定を行った.

2 図には, 横軸に $\mathrm{V} / \mathrm{Fe}+\mathrm{Ti}$ を, 縦軸には $\mathrm{Zn} / \mathrm{Fe}+$ Ti をとって, No. 1 から No. 4 までの土壤の強磁性鉱 物の元素の重量比の組合子㚾示した。この図に示したべ ルトは，先にSHoji et al. (1975) および庄子 (1977) が 岩質判定に用いたものである. 本地域のテフラの強磁性 鉱物もこのベルト上にまとまって分布しており，石英安

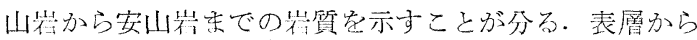

村崎野軽石層までのテフラは，図 1 に示したように，便 宜上 $M-1$ から $M-6$ までに分けられる.

金ケ崎段丘の黑ボク土 No. 1 の $\mathrm{A}_{1}$ 層は，強磁性鉱 物の化学組成から，上部約 $5 \mathrm{~cm}$ が $\mathrm{M}-1$ に，その下部 が M-2 に区分できる. V-Zn ベルトより，いずれも 石英安山岩の領域に属するが， M-2 はベルト上で安山 岩の領域に接近している.しかしながら $A_{1}$ 層の下位 にある河川堆積物は， $\mathrm{V}-\mathrm{Zn}$ ベルトより大きく離れた M-7 の位置に存在する. 一方本地域の平安初期の堅穴 中に発見された新鮮火山灰は $\mathrm{M}-1$ よりややはなれた M-1'にまとまって分布する. もし $\mathrm{M}$-1 の中にこの 新鮮火山灰が含まれているなら， M-1には $\mathrm{M}-1$ 他に，M-1 よりさらに珪長質の他の火山灭が混合して いることになる。

表 2 に示した重鉱物組成によると， $\mathrm{A}_{11}$ 層から $\mathrm{A}_{13}$ 層 
表 2 重 鉱物組成

\begin{tabular}{|c|c|c|c|c|c|c|c|c|}
\hline 試 & 層 位 & 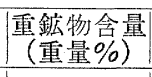 & $\begin{array}{l}\text { シソ数石 } \\
\text { (粒数\%) }\end{array}$ & $\begin{array}{l}\text { 通普輝石 } \\
(\text { 粒数 \%) }\end{array}$ & $\begin{array}{l}\text { 角閶石 } \\
(\text { 粒数\%) }\end{array}$ & $\mid$\begin{tabular}{|c|}
$\mid$ 強磁性龯物 \\
$($ 粒数\%
\end{tabular} & $\begin{array}{l}\text { 不 明 } \\
\text { (粒数\%) }\end{array}$ & $\begin{array}{l}\text { 強磁性鑃物に } \\
\end{array}$ \\
\hline $\begin{array}{r}\text { 新鮮火山灰 } 1^{*} \\
\text { No. } 1 \text { - } 1 \\
-2 \\
-3 \\
-4\end{array}$ & $\begin{array}{l}A_{11} \\
A_{11} \\
A_{12} \\
A_{13}\end{array}$ & $\begin{array}{l}8 \\
6 \\
6 \\
7 \\
4\end{array}$ & $\begin{array}{l}50 \\
34 \\
47 \\
44 \\
39\end{array}$ & $\begin{array}{l}15 \\
15 \\
15 \\
23 \\
14\end{array}$ & $\begin{array}{r}0 \\
4 \\
9 \\
5 \\
12\end{array}$ & $\begin{array}{l}35 \\
47 \\
27 \\
23 \\
35\end{array}$ & $\begin{array}{l}2 \\
1 \\
5\end{array}$ & $\begin{array}{l}M-1 ' \\
M-1 \\
M-2 \\
" \prime \prime \\
" 1\end{array}$ \\
\hline 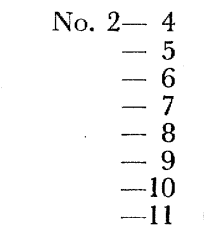 & 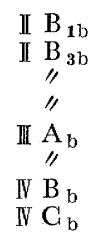 & $\begin{array}{l}20 \\
21 \\
19 \\
19 \\
25 \\
42 \\
36 \\
58\end{array}$ & $\begin{array}{l}42 \\
46 \\
38 \\
32 \\
33 \\
45 \\
54 \\
33\end{array}$ & $\begin{array}{r}2 \\
1 \\
1 \\
1 \\
1 \\
5 \\
18 \\
26\end{array}$ & $\begin{array}{r}4 \\
2 \\
3 \\
4 \\
6 \\
3 \\
\text { tr. } \\
0\end{array}$ & $\begin{array}{l}46 \\
45 \\
53 \\
59 \\
57 \\
45 \\
26 \\
41\end{array}$ & $\begin{array}{l}6 \\
6 \\
5 \\
4 \\
2 \\
3 \\
2\end{array}$ & $\begin{array}{l}M-3 \\
M-4 \\
M-5 \\
M-6\end{array}$ \\
\hline
\end{tabular}

* 平安初期の堅穴中で採取した火山灰

表 3 重 鉱物 の 溶蝕程 度

\begin{tabular}{|c|c|c|c|c|c|c|c|c|c|c|c|}
\hline \multirow{2}{*}{ 試 } & \multirow{2}{*}{ 料 } & \multirow{2}{*}{ 層位 } & \multicolumn{4}{|c|}{ シソ輝石の溶蝕程度* } & \multicolumn{4}{|c|}{ 普通輝石の溶蝕程度* } & \multirow{2}{*}{$\begin{array}{l}\text { 強磁性鉱物に } \\
\text { 上る目材区分 }\end{array}$} \\
\hline & & & (棓数\%) & $\begin{array}{c}1 \\
(\text { 粒数\%) }\end{array}$ & $\left(\begin{array}{c}2 \\
(\text { 粒数\%) } \\
\end{array}\right.$ & (粒数\%) & $\begin{array}{c}0 \\
(\text { 粒数\%) }\end{array}$ & $\left(\begin{array}{c}1 \\
(\text { 粒数\%) }\end{array}\right.$ & $\begin{array}{c}2 \\
(\text { (粒数\%) } \\
\end{array}$ & $\begin{array}{c}3 \\
(\text { (粒数\%) } \\
\end{array}$ & \\
\hline \multicolumn{2}{|c|}{$\begin{array}{|cl|}\text { 新鮮火山灰 } & 1 * * \\
\text { No. } 1- & 1 \\
2 \\
3 \\
4\end{array}$} & $\begin{array}{l}A_{11} \\
A_{11} \\
A_{12} \\
A_{13}\end{array}$ & $\begin{array}{l}30 \\
33 \\
25 \\
31 \\
32\end{array}$ & $\begin{array}{l}67 \\
58 \\
46 \\
47 \\
48\end{array}$ & $\begin{array}{r}3 \\
8 \\
25 \\
18 \\
18\end{array}$ & $\begin{array}{l}0 \\
0 \\
4 \\
4 \\
2\end{array}$ & $\begin{array}{l}10 \\
10 \\
10 \\
10 \\
15\end{array}$ & $\begin{array}{l}76 \\
62 \\
56 \\
59 \\
32\end{array}$ & $\begin{array}{l}14 \\
28 \\
26 \\
24 \\
32\end{array}$ & $\begin{array}{r}0 \\
0 \\
8 \\
6 \\
21\end{array}$ & $\begin{array}{l}M-1 \\
M-1 \\
M-2 \\
\prime \prime \\
" 1\end{array}$ \\
\hline \multicolumn{2}{|c|}{ No. $\begin{array}{r}2-4 \\
-5 \\
-6 \\
=7 \\
=8 \\
-9 \\
=10 \\
-11\end{array}$} & $\begin{array}{l}\text { II } \mathrm{B}_{1 \mathrm{~b}} \\
\mathbb{I I} \mathrm{B}_{3 \mathrm{~b}} \\
\text { "I }^{\prime \prime} \\
\text { "II } \\
\text { II } \mathrm{A}_{\mathrm{b}} \\
\mathbb{N} \mathrm{B}_{\mathrm{b}} \\
\mathbb{I V} \mathrm{C}_{\mathrm{b}}\end{array}$ & $\begin{array}{r}3 \\
2 \\
2 \\
0 \\
0 \\
1 \\
4 \\
42\end{array}$ & $\begin{array}{r}33 \\
21 \\
9 \\
5 \\
6 \\
7 \\
80 \\
54\end{array}$ & $\begin{array}{r}40 \\
34 \\
23 \\
30 \\
25 \\
31 \\
16 \\
4\end{array}$ & $\begin{array}{r}24 \\
43 \\
66 \\
65 \\
69 \\
61 \\
0 \\
0\end{array}$ & $\begin{array}{l}= \\
= \\
= \\
= \\
=\end{array}$ & $\begin{array}{l}= \\
= \\
= \\
= \\
=\end{array}$ & $\begin{array}{l}= \\
= \\
= \\
= \\
=\end{array}$ & $\begin{array}{l}= \\
= \\
= \\
= \\
=\end{array}$ & $\begin{array}{l}M-3 \\
M-4 \\
M-5 \\
M-6\end{array}$ \\
\hline$*$ & 溶蝕程度 & & & 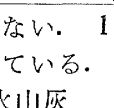 & $\frac{1}{4}$ & 人受 & & 溶食 & 程度 & $\tau$ & \\
\hline
\end{tabular}

までは類似した組成を示し，火山灰層相互の識別がかな り困難であるが， $\mathrm{A}_{12}$ 層と $\mathrm{A}_{13}$ 層との間に若干の差が 西るようにみられる。これに対して堅穴中の新鮮火山灰 は角閃石を全く含まないことで，他の火山灰層と明確に 区別される.

表 3 に示した普通輝石の溶蝕程度によれば，堅穴の新 鮮火山灰と M-1 属する火山灰はともに風化が進えで 括らず，他の火山灰から 明瞭に識別される。したがっ て, 先に示した強磁性鉱物の分析結果と合せる之 $\mathrm{M}-1$ には堅穴中に見出された新鮮な火山灰と，他の火山灰が 含安れていることが分る．M-2 湴通輝石の溶蝕程度 から重鉱物組成による場合と同じように，さらに 2 つに 分けられる可能性がある. 以上から $\mathrm{A}_{1}$ 層の母材は，珪 長質の少なくとも $3 \sim 4$ 校の火山灰層からなることが明
らかである.なお普通輝石の溶蝕程度からこれらの火山 兏の年代堂推定すると，5,000 年以下と夕られる（MAsur et al., 1973, Sнојг et al., 1974).

村崎野段丘の黒ボク土 No. 2 を図 2 の V-Zn ベルト でみると， $A_{1}$ 層の土壤はすべて $\mathrm{M}-2$ 亿流とまって 分布する. この図上での $\mathrm{M}-2^{\prime}$ の位置は $\mathrm{M}-1, \mathrm{M}-2$, M-3 のほぼ重心の位置にあることから，乙の $\mathrm{A}_{1}$ 層は 金ケ崎段丘の $\mathrm{A}_{1}$ 層の母材に, さらに $\mathbb{I} \mathrm{B}_{1 \mathrm{~b}}$ 層之同じ 火山灰の一部が混合しているものとみられる. 本地域で は, 繩交中期から平安初期までの遺跡が数多くみられる が，その分布は後述するように，とくに村崎野段丘に集 中して打り(図 3), No. 2 の土壤断面の $\mathrm{A}_{1}$ 層加ら女土 器の破片が見出されたことからみて，乙のような母材の 混合は人為の影響によるものであることが明らかであ 
る. $\mathrm{A}_{1}$ 層の重鉱物組成および溶蝕程度の決定は，この 土壤の人為的混合が進えでいるので省くことにした。

前報（庄子·小野，1978）では II $\mathrm{B}_{1 \mathrm{~b}}$ 層は，赤味が強 くまた粘土含量がきわめて高くて緻密であることから， この層がかなり長期間地表風化を受けたことがあるもの と推定した. 図 2 に示した V-Zn ベルトによれば, II $B_{1 b}$ 層から II $\mathrm{B}_{3 b}$ 層までの母材は $\mathrm{M}-3$ と $\mathrm{M}-4$ に分けら れ，M-3 には II $\mathrm{B}_{1 \mathrm{~b}}$ 層と II $\mathrm{B}_{3 \mathrm{~b}}$ 層の上部が， $\mathrm{M}-4$ に は II $\mathrm{B}_{3 \mathrm{~b}}$ 層の大部分が含まれることがわかった（図 1) また表 2 の重鉱物組成によると $\mathrm{M}-3$ と $\mathrm{M}-4$ の間に はシソ輝石と強磁性鉱物の含量に若干の差が認められ る. 一方普通輝石の溶蝕程度は II $\mathrm{B}_{1 \mathrm{~b}}$ 層以下で著しく進 み，その粒数が減少して溶蝕判定が困難となる. そこで II $\mathrm{B}_{\mathbf{1} \mathrm{b}}$ 層以下については普通輝石の代りにシソ輝石を使 って風化状態を見ることとした・表 3 に見られるよう に，M-3 と M-4 とではシソ輝石の溶蝕程度に明膫な 差が存在する。また同じ $\mathrm{M}-3$ に属する II $\mathrm{B}_{1 \mathrm{~b}}$ 層は， II $\mathrm{B}_{\mathbf{3 b}}$ 層の上部よりも溶触程度がやや低いことが注目さ れる。この理由としては，II $\mathrm{B}_{\mathbf{1}} \mathrm{b}$ 層が長期間地表風化を している間に少量の新しい火山灰が添加されたか，ある いは， $\mathrm{A}_{1}$ 層の一次鉱物が若干混入していることが考光 られる。

最近No. 2 地点の近くの下成沢遺跡で発見された旧石 器は数万年 (林, 1973), あるいは1.5〜1.8万年のもの （渋谷，私信）と推定されている. その出土寸る位置は M-4 の上部にもっとも集中していることから， M-3 と M-4 との間にも年代的に若干の間陌があったと思わ れる.さらに北上市西方の藤沢遺跡で発見された旧石器 の推定年代は 1.3〜 1.5 万年であって，その出土位置は II $\mathrm{B}_{1 \mathrm{~b}}$ 層から II $\mathrm{B}_{3 \mathrm{~b}}$ 層の上部, すなわち $\mathrm{M}$-3 である (梶原, 私信). このことから, 従来 $\mathbb{I} \mathrm{B}_{1 \mathrm{~b}}$ 層から II $\mathrm{B}_{3 \mathrm{~b}}$ 層玉で同一の母材と夕られていた火山灰が，年代が 1 〜 数万年前の少なくとも 2 なし 3 枚の安山岩質火山灰層 よりなっていることが分る. したがって，M-2 と $\mathrm{M}-$ 3 との間には 5,000 年前後の 時間間陌があること落 えられる。

III $\mathrm{A}_{\mathrm{b}}$ 層以下溞磁性鉱物の化学組成から，いずれも 安山岩質のテフラであるが，III $\mathrm{A}_{\mathrm{b}}$ 層が $\mathrm{M}-5, \quad \mathbb{N} \mathrm{B}_{\mathrm{b}}$ 層 と $\mathrm{NC}_{\mathrm{b}}$ 層とが $\mathrm{M}$-6 に含まれる. しかしながら噴出 源である焼石岳に近づくにつれて， III $\mathrm{A}_{\mathrm{b}}$ 層から $\mathbb{N} \mathrm{C}_{\mathrm{b}}$ 層までは同一の連続した降下物であることを示す特徴 が認められる. 一方, 表 2 の重鉱物組成では III $\mathrm{A}_{\mathrm{b}}$ 層に は角閃石が含まれるのに対して， N $\mathrm{B}_{b}$ 層や $N \mathrm{C}_{b}$ 層で 法角閃石が存在せず，普通輝不がかなり多く夕られる。
山田・庄子（1976）は，同じ火山から噴出したテフラが 軽石から火山灰へと岩相が变化する過程で, 珪酸鉱物や 重鉱物組成に変化のあること觉出した. 本地域の村崎 野軽石層（VI $\mathrm{B}_{\mathrm{b}} ， \mathbb{N} \mathrm{C}_{\mathrm{b}}$ ) からその上部の火山庅層 (II $\mathrm{A}_{\mathrm{b}}$ ) への变化過程でも, 山田らの認めたような鉱物組成の变 化が起ったものと考えられる.ただし，赤味のあるIII $\mathrm{A}_{\mathrm{b}}$ 層のシソ輝石は $\mathrm{N} \mathrm{B}_{\mathrm{b}}$ や $\mathbb{N} \mathrm{C}_{\mathrm{b}}$ 層のものに比べて非常に 風化が進えでおり， II $\mathrm{B}_{1 \mathrm{~b}}$ や II $\mathrm{B}_{3 \mathrm{~b}}$ 層に比べても風化が 進えでいる.このことは， III $\mathrm{A}_{\mathrm{b}}$ 層もまたかなり長い間 地表風化を受けたことのあることを示している.

以上から, 中川ほか (1963) によって, 報告された黒 沢尻火山灰は，間歇的に何度も降灰がくり返された累積 性のものであること，またその岩質は石英安山岩質から 安山岩質にわたっていること，さらにその年代は 1,000 年程度から数万年ないし，それ以上におよてでいること などが分った。

次に同様の方法により，他の土壤断面の母材の識別要 行った結果を図 1 にまとめ, さらに断面相互に詨比を行 った結果をも記載する。

村崎野段丘の淡色黑ボク土ーII (No. 3) 注，すでに前 報で指摘しているように，同じ段丘上の黒ボク士（No. 2）の $A_{1}$ 層に相当する部分が削剝流亡して，M-3 部分 が現在の表層となっていることが明らかである・金ケ崎 段丘の土壤とちがって, 村崎野段丘や西根段后の火山灰 土壤の II $\mathrm{B}_{1 \mathrm{~b}}$ 層から II $\mathrm{A}_{\mathrm{b}}$ 層までは, 粘土含量が高く緻 密なため，植生が破壞された場合には金ケ崎段丘の土壤 に比べて, 表面流去水による土壤侵蝕を受け易いである う. No. 3 の淡色黒ボク土ーII 人為および地形的な影 響によって土壤侵蝕が促進されたものとみられる。 方，西根段丘の淡色黒ボク土一II (No. 4) も削刽土壤で あるが，この土壤は開析の進んだ地形の頂面 (summit) にあって，No. 3 よりもさらに削涂が進えている.

多湿黒ボク土は金ケ崎段丘の沩水带から呞端にかけて の排水不良地と，村崎野及び西根段丘開析谷に分布して いる. 後者は, 図 1 に示されているように，金ケ崎段 丘のものと異なって谷部に崩積物質が再堆積して生成し たものである・村崎野段丘の谷部の多湿黑ボク土（No. 7) は, 最上部の $\mathrm{A}_{11}$ 層には $\mathrm{M}-4$ が堆積しているが, $\mathrm{A}_{12}$ 層から $\mathrm{A}_{13}$ 層までは $\mathrm{M}-2, \mathrm{M}-3, \mathrm{M}-4$ が混合 している. また西根段斥を刻む谷の多湿黑ボク土 No. 8 は，腐植層が $160 \mathrm{~cm}$ と著しく厚いが，その最下部には M-3 が，その上部には M-4 が逆転して堆積してい る.として最上部には年代の新しい $\mathrm{M}-2$ が再堆積して いることがわかった。 


\section{IV. 総 合 考 察}

以上の研究により，本地域に分布する火山兏土壤の目 材の実態がか子り明らかになったので，その成果㳊もと

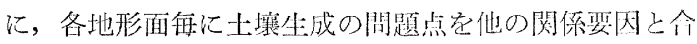
せて総合的に考察する.

金ヶ崎面上の土壤は，扇状地形成後に降下した若い眓 積性火山存 $(1,000 \sim 5,000$ 年と推定) に由来し, 若返り タイプの腐植層を形成している（第 1 報, 表 1 ). 出現 する土壤の種類は，黑ボク土，淡色黒ボク土ーI，および 多湿黒ボク土の 3 種類である（第 1 報，図 2). これら の土壤の生成は, 扇状地に特徵的な微地形（微高地であ る旧中州と低地である網状流跡）とその構成堆積物の種 類 (砂磞堆と細粒堆積物), さらに排水条件（たと光ば, 湧水带の影響）などに密接に関係している. 一方図 3 に示された対集地域の遺跡分布図（北上市史，1968；金 ケ崎町史，1965，遺跡資料より作製）によると，金㥓 面には遺跡が少く，とくに扇頂から湧水带末での排水良

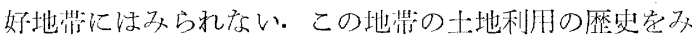

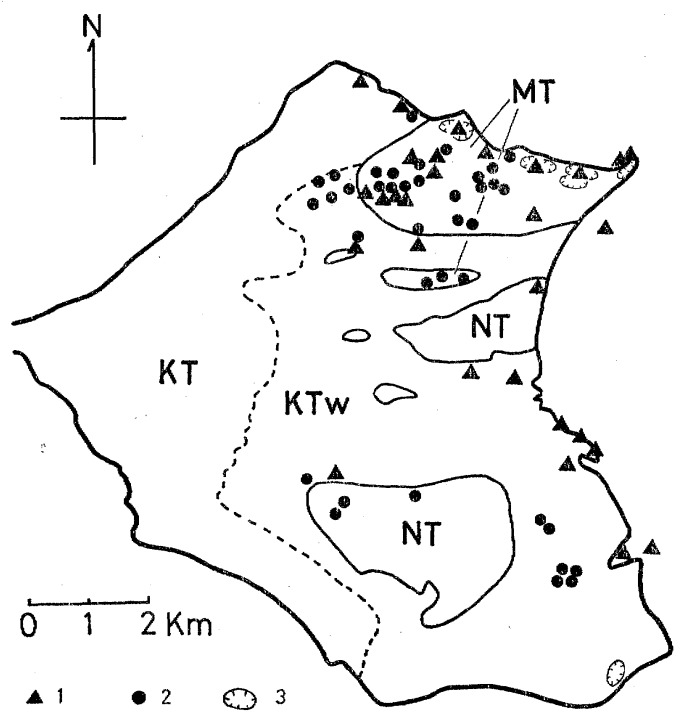

図 3 遺跡の分布図

凡例 1. 繩文土器, 石器, 2. 土師器, 須恵器, 3. 古代䀳跡.

$\mathrm{KT}$; 金厅崎段丘 (排水良好)，KTw；金厅崎 段丘（排水不良）， MT；村崎野段丘， NT； 西根段丘。

北上市史刊行会 (1968)，全乃崎町史編さえ委 員会 (1965)，成沢，下成沢遺跡調查団 (1972), 上大谷地遺跡調查団（1972）の資料を合せて 作成.

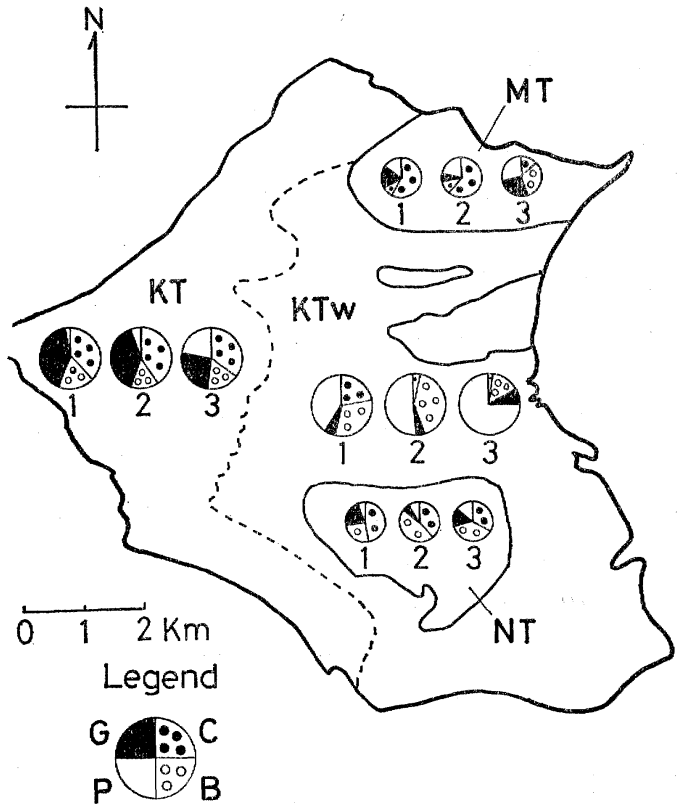

図 4 植生および土地利用の変蒛

国土地理院 5 万分の 1 地形図，1:1913年，2:1933 年，3:1968 年より作製.

凡例 $\mathrm{G}$; 草地及び原野, $\mathrm{C}$; 針葉樹林, $\mathrm{P}$; 水田, $B$; 広葉樹林. その他经第 3 図参照.

ると，德川㭙代には未だ農地としての利用が進すず，原 塌として放置されていたように夕られる（金ヶ崎町史， 1965). 宗た闵 4 に禁とめられた近年の土地利用の变遷 を多ても，この地带汪草地や原野がもっとも広く分有し ていたことがわかるそそのためこの地带の土壤は，村崎 野段丘の土龒のような母材の人為攪乱定強く受けること が少なく，しかも黒ボク土の生成に密接に関係している と夕られるススキなどの草本植生（加藤，1976）が比較 的よく発達していたことがわかる. もらろえ本地域の植 生の極相は広葉樹林であるので，草本植生の発達は人為 の影響によることは明らかである。

金ケ崎面の淡色黒ボク土ーI は，土色は黒味が強く腐 植含量が高いが，扇状地の砂礫堆積物上に降下した火山 灰に由来しているために，腐植層の厚さがうすい土壤で ある（庄子・小野，1978，第 1 報表 1 ）。

金ケ崎面で扇状地の湧水帯から高端にかけては，多湿： 黑ボク土が広く分布する.そこで湧水がかんがい水とし て利用出来るため，かなり古い時代から開田が進められ ていたように思われる（金ケ崎町史，1965).

村崎野段丘は，金ケ崎段正よりも全体としての勾配は ゆるやかであり，開析が進んでい尔い（籘1 報)。この 
地形面上の黒ボク土および淡色黒ボク土ーII は，ともに 年代が数万年ないしそれ以上と推定される村崎野軽石層 を最下部とし，その上に 1 ～数万年とみられる何枚かの 火山灰が累積している（図 1)。最上部の腐植層は母材 の人為的攪乱が進み，その大部分は金ケ崎面の黑ボク土 の $\mathrm{A}_{1}$ 層と同じものであるが，そのほかに下位の II $\mathrm{B}_{1 \mathrm{~b}}$ 層の一部が人為的に混入している（図 1). 遺跡の分布状 態(図 3)をみると，村崎野段丘に濦交中期から平安初 期までの遺跡がもっとも集中しており，この段丘面上で の土壤生成が，調查地域の中で人為の影響をもっとも強 く受けているように夕られる(図 1 と図 2 ).土地利用の 变遷（図 4 ）をみると，村崎野段丘には近年まで森林が 比較的広くみられたが，最近に至ってかえがい用水が確 保され，開田名急速に進められている。なお，村崎野軽 石は夏油川扇状地の構成堆積物中に成層して含字れてい る場所が存在すること，また $\mathbb{I} \mathrm{B}_{1 \mathrm{~b}}$ 層から $\mathbb{I} \mathrm{B}_{3 \mathrm{~b}}$ 層まで の火山灰が扇状地堆積物の最上部には認められないこと から，この扇状地は数万年以上前から，1 万年前位まで にわたって形成されたものとみられる。なお，中川ほか （1963）はこの扇状地を立川ないし武蔵野面に対比した。

村崎野段丘の淡色黒ボク土一林 は，黑ボク土の分布す る場所よりもやや勾配の大きい場所に比較的多く久られ る.しかし先に述べたように，乙の段丘での人為の影響 が大きいことから，削涂作用は人為によって著しく促進 されたとみられる．この削制作用により黒ボク土の最上 部の腐植層に 相当する 部分が失われ，その下位にある II $\mathrm{B}_{1 \mathrm{~b}}$ 層が露出して, 現在の腐植層を形成している. 淡 色黒ボク土ーII 西根段丘上でも削涂土壤であるが，こ の土壤の腐植の集積能力や腐植化の進行などに関係する 要因については，さらに今後の研究が待たれる.

村崎野段丘の地域の多湿態ボク土は谷部に再積積した 土壤である (図 1). この段丘は西根段丘のように開析 が進えでいないため，その分布は限られている.

西根段丘は年代が古くて開析がもっとも進み，急傾斜 面に置きか兄られた所が多い. 頂面 (summit) から背斜 面 (backslope) にかけては排水が良好であり，削鋓によ る淡色黒ボク土ーII が生成している（図 1). 一方斜面下 部 (footslope) から谷底部(valley bottom)にかけては, その上位から侵蝕移動した土壤が再積し，著しく厚い腐 植層をるつ多湿黑ボク土が生成している（図 1)。西根 段丘の地域は，図4の土地利用状況をみても林地の割合 が圧倒的に大きいが，地形的には土壤侵蝕をもつともう け易い条件をもっており，人為（例えば，山火事による 植生の破壊など）によって土壤侵蝕一再積移動を一層促
進したものとみられる.

以上から，本地域の火山灰土壤の生成には，地形々母: 材に加えて, 人為や植生もまた密接に関係していること が明らかとなった。

\section{V. 要}

約

第 1 報で明らかにされた各種の火山灰土壤について, 母材と土壤生成の関係を研究した結果, 母材の累積的堆 積状態が，各地形面での土壤生成に密接に関係している ことが明らかにされた。亦た本研究では，テフラ中の強 磁性鉱物の化学組成が，テフラの識別に有效であること も明らかにされた。

研究対象とされた村崎野軽石層までのテフラは, 上部 より $1,000 \sim 5,000$ 年と推定される石英安山岩質の累積 火山灰（金ケ崎および村崎野面の黑ボク土の $\mathrm{A}_{1}$ 層)， 10,000 数万年 と推定される安山岩質の累積性火山灰 (例光ば村崎野面の黒ボク土の $\mathbb{I} \mathrm{B}_{\mathrm{b}}$ 層)，および数万年 ないしそれ以上の安山岩質の火山灰之村崎野軽石層（例 えば村崎野面の黒ボク土の II $\mathrm{A}_{\mathrm{b}}$ 層以下）よりなってい る. そして，このような累積性の母材は，間けつ的な降 灰によって供給されたため，それぞれかって地表風化を 受け，下部ほどよく風化していることが分った。

金ケ崎段丘上の火山灰は，すべて若い累積性火山灰 $\left(1,000 \sim 5,000\right.$ 年）を母材とする若返りタイプの $\mathrm{A}_{1}$ 層 を形成している．そして火山灰層の下位には扇状地を構 成する堆積物が存在する。

村崎野段丘では母材の人為的混合, 削涂, 移動再積が 各土壤の生成に密接に関係している. この段丘上の黒ボ ク土の $\mathrm{A}_{1}$ 層は，金ケ崎段丘の黒ボク土の $\mathrm{A}_{1}$ 層の母材 に加えて，下位の $\mathbb{I} \mathrm{B}_{\mathbf{1 b}}$ 層の火山灰も一部含まれてい る.しかもこれらの母材が人為的によく混合されている ことが分った．淡色黒ボク土ーIIは，人為の影響を強く 受けて, 黒ボク土の $\mathrm{A}_{1}$ 層に相当する母材が削刢されて 生成している.一方多湿黒ボク土は，再積性土壤である。

西根段丘の地域の土壤は，地形の開析が進えでいるた め，頂面 (summit) から背斜面 (backslope) までは 削涂土壤である淡色黒ボ 土ーII が，また斜面の下部 (footslope) から谷底部 (valley bottom) まで再積性の 多湿黒ボク土であることが明らかとなった・なお本地域 の火山灰土壤の生成には, 地形と母材に加えて, 人為や 植生もまた密接に関係していることが，考察された。

\section{謝 辞}

本研究（第 1 報および第 2 報）を実施するにあたって， 多くの方々から多大の御援助をいただいた。本地域のテ 
フラの分布および編年については，東北大学理学部地質 学講座の中川久夫助教授に, また地形学的問題について ·, 自然地理学講座の西村嘉助教授に有益な御教示をい ただいた．岩手県教育委員会の林謙作氏（現北海道大学 助教授), 菊地郁雄氏, 他多くの方々，拉よび東北大学 交学部考古学講座の岡村道雄氏を始妨るる多くの方々 から，本地域の遗跡に関する貴重な情報を提供していた だいた。農業技術研究所天野洋司室長には, 土壤調査, 分類, さらに原稿のとりまとめにあたっても, 多大の御 援助を頂載した。岩手県農業試験場県南分場佐々木信夫 次長ならびに遠藤征彦氏には貴重な土壤調查資料を提供 していただいた。現地調査にあたっては，岩手県立六原 農場佐藤健部長，清原悦郎主任（現県農産普及課專門技 術員）他多くの方々から多大の御援助をいただいた・東 北大学農学部農業立地学研究室の三枝正彦助手を始めと する多くの方々から絶えず貴重な御意見や後援助を頂載 した.ここに以上の方々に対して深く感謝申し上げる.

\section{引用交献}

林 謙作 (1973) 相去台地の先史特代. 日本地質学会, 第 80 年総会見学旅行 2, 北上川低地带の鮮新統，第 四系, 地形, p. 33 .

上大谷地遺跡調查団 (1972) 上大谷地遺跡調查概要. 金ケ崎町史編さん委員会 (1965) 金ケ崎町史. 加藤若朗 (1976) 黑ボク土(火山灰土壤). 日本の土壤, アーバンクボタ, No. 13, p. 12-13.

北上市史刊行会 (1968) 北上市史 I. 原始, 古代.

弘法健三・大羽 裕 (1973) 風化の程度と母材型とによ る火山灰土壤の類別, 本邦火山灰土壤の生成論的研究 (第 2 報). 土肥誌, 44, p. 41-46.

Masur, J., Shoji, S., Saigusa, M., Ando, H., Kobayashi, S., Yamada, I., and SaIto, K. (1973) Mineralogical and agrochemical properties of Kawatabi volcanic ash soil. Tohoku J. Agr. Rer., 24, p. 166174.

MehrA, O. P. and JAckson, M. L. (1960) Iron oxide removal from soils and clays by a dithionite-citrate system with sodium bicarbonate buffer. Clays Clay Miner., 7, p. 317-327.

長友由隆・庄子貞雄・小林進介 (1976) 南九州のアカ木 ヤの堆積状態と強磁性鉱物の化学組織について, アカ ホヤの土壤肥料学的研究 (第 1 報). 土肥誌, $47, \mathrm{p}$. $342-348$.

中川久夫 - 岩井淳一 - 大池昭二 - 小野寺信吾・森由紀子. 木下 尚 - 竹内貞子 - 石田伥三 (1963) 北上川中流沿 岸の第四系および地形，北上川流域の第四紀地史 (2). 地質雑，69，p. 219-227.

成沢 - 下成沢遺跡調查団 (1972) 成沢 - 下成沢遺跡現地 説明会資料，p. 1-10.

庄子貞雄 (1977) 強磁性鉱物の化学組成による火山灰の 起源, 岩質の決定. 土肥要旨集, no. 23, シンポジウ 厶 I -5 , p. $187-188$.

庄子貞雄 - 小林進介 - 増井淳一 (1974) 火山灰中の強磁 性鉱物の化学組成と噴出源との関係について.岩鉱誌, 69, p. $110-120$.

Shoji, S., Kobayashi, S., Yamada, I., and Masui, J. (1975) Relationships between the geochemistry of ferromagnetic component and the chemical properties of air-borne pyroclastic materials. J. Japan Assoc. Min. Petr. Econ. Geol., 70, p. 12-24.

庄子貞雄 - 小野剛志 (1978) 岩手県北上市付近の火山灰 土壤の生成について，第 1 報，地形と土壤生成，第四 紀研究, 16, p. 247-254.

ShojI, S., Yamada, I., and Masui, J. (1974) Soils formed from the andesitic and basaltic volcanic ashes, I The nature of the parent ashes and soil formation. Tohoku J. Agr. Res., 25, p. 104-112.

山田一郎 · 庄子貞雄 (1976) 火山灰の化学的括よび鉱物 学的研究 (4) 珪酸鉱物について. 土肥要旨集, No. 22 , p. 29 . 